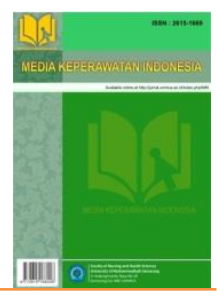

Research article

\title{
Mother's Experience Provide Burn First Aid to Younger Children
}

\author{
Hanifah Nur Laily ${ }^{1}$, Elsa Naviati ${ }^{2}$
}

1,2 Program Studi Ilmu Keperawatan, Fakultas Kedokteran, Universitas Diponegoro

\section{Article Info}

Article History:
Accepted September 1st
2019

\section{Key words:}

Burns, Child; First Aid; Injury

\section{PENDAHULUAN}

Cedera yang sering dialami pada anak-anak seperti kecelakaan kendaraan, terjatuh, terkena benda-benda tajam/tumpul, tenggelam dan luka bakar (Santoso \& Sulistiowati, 2013). Data Riset Kesehatan Dasar Jawa tengah pada tahun 2013 prevalensi terjadinya cedera di Jawa Tengah sebesar 7,7\%, penyebab cedera yang sering terjadi pada anak-anak umur 14 tahun yaitu jatuh $(74,6 \%)$, kecelakaan sepeda motor $(10,6 \%)$, dan terbakar (1,2\%). Cedera luka bakar pada anak sering terjadi di rumah terutama di pedesaan, biasanya disebabkan karena tersiram air
Abstract

The incident of burns in children aged 1-4 years is risk get disabled and death. This is caused the children still do not understand the danger and handling it. The role of a mother is important to give first aid to reduce the severity. First aid for burns that are still often given use such as toothepaste, saliva, coffe, soy sauce and margarine. The purpose of this study to describe experience of mothers provide first aid in burns of children aged 1-4 phenomenologycal method. The sampel of this study was a mother have children aged 1-4 years who had suffered burn in periode of less than 9 mounth determined by the purposive method. Collecting data was conducted by in-depth interviews (1) first aid, (2) burns, (3) burns reaction, (4) psychological impact, (5) mother's perception of burns, (6) actions to reduce injury. Classification of burns found is mild to moderate burns. First aid for burns done by mothers using aloe vera, water, cooking oil, toothpaste, and tender care (oriflamme). The mother's reaction to knowing that her child had burned was panic, worry, shoock, and pain. First aid for child burns given by the mother using aloe vera, water, cooking oil, toothpaste, and tender care (oriflamme).

\footnotetext{
Corresponding author:

Hanifah Nur Laily

hanifahnurlaily@gmail.com

Media Keperawatan Indonesia, Vol 2 No 3, Oktober 2019

e-ISSN: 2615-1669

DOI:10.26714/mki.2.3.2019.90-96
}

panas (Kuschithawati, 2007). Selain itu, penyebab luka bakar pada anak-anak dapat disebabkan oleh uap panas, kejadian tumpahnya minuman panas, dan kecelakaan ketika bermain (Mignon, 2008).

Pemberian pertolongan pertama yang tepat pada orang yang mengalami luka bakar merupakan langkah yang penting untuk mengurangi keparahan cedera, nyeri, dan komplikasi pasca luka bakar (Lam, Li F, Tuan CA, dan Huong, 2017). Pemberian pertolongan pertama pada orang yang mengalami luka bakar merupakan salah satu penanganan gawat darurat fase prehospital, dimana keluarga merupakan 
penolong pertama sebelum dibawa ke rumah sakit (Sari, 2015). Selain itu, adanya tindakan pencegahan dan pemberian pertolongan pertama yang benar pada cedera luka bakar terbukti mengurangi morbiditas dan mortalitas dari luka bakar, selain itu juga dapat berdampak menguntungkan untuk mengurangi morbiditas terkait biaya perawatan kesehatan, melalui pembatasan kerusakan jaringan, hingga mengurangi adanya tindakan pembedahan (Kattan, AlShomer, Alhujayri, Addar, dan Aljerian, 2016). Berdasarkan hasil penelitian di Desa Jombor Bendosari Sukoharjo yang mewawancarai 43 ibu yang anaknya pernah mengalami luka bakar penanganan yang dilakukan pertama kali yaitu dengan menggunakan pasta gigi dan lidah buaya (Muyyassaroh, 2015). Pemberian pertolongan pertama dengan menggunakan bahan-bahan tersebut akan memperburuk cedera dan menciptakan lingkungan yang dapat membuat infeksi, serta pengobatan tidak bermanfaat untuk menyembuhkan luka bakar (Kattan et al, 2016). Penelitian ini bertujuan untuk mengetahui gambaran pengalaman ibu melakukan pertolongan pertama pada luka bakar anak umur 1-4 tahun di Kota Semarang.

\section{METODE}

Jenis penelitian ini menggunakan penelitian kualitatif dengan pendekatan fenomenologi deskriptif dengan teknik pengambilan sampel menggunakan teknik nonprobabilty sampling dengan teknik purposive sampling. Jumlah partisipan sebanyak 7 partisipan. Penelitian dilakukan secara door to door mulai pada bulan mei 2019 di kota Semarang. Analisa data ini menggunakan model colaizzi dengan validitas data diperoleh dari triangulasi teori dan member check. Etika penelitian diperoleh dari Departemen Keperawatan Fakulatas Kedokteran Universitas Diponegoro nomor 04/EC/KEPK/D.Kep/III/2019.

\section{HASIL}

Setelah dilakukan wawancara kepada 7 partisipan dengan rata-rata usia partisipan 29-45 yang memiliki pendidikan terakhir dari SMP, SMA, dan S1 dengan penyebab luka bakar karena terkena air panas, knalpot, terkena bara api, terkena korek dan terkena lem bakar. Kurun waktu kejadian luka bakar pada penelitian ini mulai dari 1 bulan hingga 9 bulan. Pada penelitian ini menghasilkan 6 tema, yaitu:

\section{Tema 1: Pertolongan Pertama}

Pada tema mengenai pertolongan pertama di bagi menjadi 5 kategori yang pertama yaitu tindakan pemberian obat tradisional/ yang dipercaya dapat menyembuhkan, persepsi ibu pemberian obat tradisional/obat yang dipercaya dapat menyembuhkan, pengendalian infeksi, pemanfaatan pelayanan kesehatan, sumber informasi. Tindakan pemberian obat tradisional/ obat yang dapat menyembuhkan didapatkakan bahwa 4 partisipan mengatakan menggunakan lidah buaya, 2 partisipan menggunakan odol dan 1 partisipan menggunakan minyak goreng dan 1 partispisan menggunakan tender care. Hal tersebeut diungkapkan oleh salah satu partisipan yaitu “...dikasih lidah buaya..." "Nggak langsung aja itu dalamnya toh langsung dicuik, terus langsung dioleskan". Pemberian hal tersebut tanpa disertai dengan pendinginan menggunakan air terlebih dahulu. Selain hal tersebut juga pengendelanian infeksi yang dilakukan yaitu dengan pemberian antibiotik hal tersebut diungkapkan oleh 2 partisipan “...Obat..." "Sirup sama bubuk, puyer..." dan "...antibiotik...". Pemanfaatan pelayanan kesehatan yang digunakan yaitu puskesmas/ RS dan apotek, hal tersebut seungkapkan oleh salah satu partisipan yang mengatakan "...tak bawa ke puskesmas, terus katanya kalau gini terus disuruh dibawa ke IGD nah terus langsung ta bawa ke IGD kan ini rawat jalan terus kontrolnya ke pak C (dr. umum)..." dan mengungkapkan membawa ke apotek yang 
diungkapkan dengan “...ke apotek toh terus tak tunjuke lukanya terus dikasih salep itu toh". Ibu mendapatkan informasi pertolongan pertama mengenai luka bakar dari tetangga, tv, internet, hal tersebut diungkapkan oleh beberapa partisipan "Omongan toh dari tetangga-tetangga", "...lihat di tv tv itu di dr. oz...", dan “...internet...".

\section{Tema 2: Keadaan luka bakar}

Berdasarkan hasil pada penelitian ini keadaan dari luka bakar dilihat dari warna, luas, keadaan kulit, dan komplikasi. Warna dari luka bakar berwarna merah hal tersebut diungakpkan oleh 6 partisipian yang mengungkapkan “...merah-merah...”, dengan luas 2 partisipan $>15 \%$ dengan 5 partisipan keadaan kulit mengelupas "Ngelonyom kabeh mbak kulite...", dan 3 partisipan mengalami komplikasi salah satunya seperti adanya demam, hal tersebut diungkapkan oleh salah satu partisipan "Panas ki suwe mbak neng omah seminggu iku panas terus..."

\section{Tema 3: Respon luka bakar}

Hasil dari wawancara ditemukan bahwa reaksi anak saat terkena luka bakar yaitu menangis sebanyak 6 partisipan dan 4 partisipan mengungkapkan apa yang di rasakannya "...dia nangis guling-guling..." dan "Nangis" "...bilang panas panas...". Mengurangi nyeri dan rewel dari anak tersebut diberikan distraksi seperti diberi jajan, diajak jalan-jalan dan di gendong hal tersebut diungkapkan oleh partisipan bahwa "Dikasih jajan..." dan “...ta ajak keliling-keliling..." "Digendong”. Reaksi dari ibu mengetahui anaknya terkena luka bakar ditemukan adanya seperti panik, kaget, khawatir, bingung dan kasian “...panik kaya merasa bersalah..."

\section{Tema 4: Dampak psikologi}

Dapak psikologi dikategorikan menajadi dampak psikologi pada anak dan pada ibu. Pada anak terdapat anak yang mengalami trauma setelah kejadian sebanyak 2 anak yang diungkangpkan bahwa "Sampai sekarang takut" "Ger ono panas wedhi mbak saprene minum air ning gelas lek ndemek panas wae neng gelas wae wis ndak mau, wis panas nganu mbak, bilang "panas wau"” dan terdapat 2 ibu juga yang mengalami trauma setelah anaknya terjadi luka bakar hal tersebut diungkapkan oleh salah satu partisipan bahwa “...ibu bapak e sing rak pernah buat teh lagi kayak orang trauma gitu..." "...merasa bersalah ono rasane piye ko yo bisa kena ko yo ra setitik..."

\section{Tema 5: Persepsi ibu mengenai luka bakar}

Persepsi ibu mengenai luka bakar dikategorikan menjadi bahaya dan tidak bahaya. 5 partisipan mengungkapkan bahwa luka bakar merupakna penyakit yang bahaya hal tersebut diungkapkan bahwa "Nek ngono kui kan biasa tapi kan nek sing bocah beda, nek wong tuwo kan gampang, gampangane ra di tutup tutup kan kena angin malah cepet garing..."

\section{Tema 6: Tindakan mengurangi kejadian terulang}

Tindakan mengurangi kejadian terulang dikategorikan pada meningkatkan waspada, tidak menggunakan barang yang dapat menyebabkan luka bakar dan tidak ada penanganan khusus. 5 partisipan mengatakan untuk mengurangi kejadian terulang dengan meningkatkan kewaspadaan hal tersebut diungkapkan dengan "...ga bisa alih pandangan lebih fokus ke anak...”, serta 1 partispisan tidak menggunakan barang yang dapat menyebabkan kejadian terulang seperti diungkapkan bahwa "...gak usah pakai dispenser itu...” dan 1 partisipan tidak memiliki tindakan penanganan khusus.

\section{PEMBAHASAN}

Luka bakar melepuh pada anak-anak perlu diberikan pertolongan pertama yaitu dengan melepasakan baju terlebih dahulu 
yang melekat pada area kulit terbakar (Moffat, 2005). Langkah pertama yang dapat dilakukan yaitu dengan mendinginkan area terbakar dengan dengan air dingin selama 10-20 menit untuk menghentikan proses terbakar, meredakan nyeri dan menimbulkan luka bakar yang lebih serius (Moffat 2005 dan Panacea 2013). Pada penelitian ini ditemukan 2 partisipan yang tidak mendinginkan terlebih dahulu area pada luka bakar, hal tersebut dapat menyebabkan adanya perluasasan diarea kulit atau membuat luka menjadi infeksi. Setelah luka lebih dingin, pakaian pada area yang terbakar dapat dilepaskan, dan jika masih terasa nyeri maka dapat dinginkan lagi (Moffat, 2005). Selain menggunakan air untuk menurunkan suhu pada area luka, lidah buaya juga dapat bermanfaat untuk mengurangi rasa sakit dan bengkak (Hamdiya, Pius, Ken, dan Ekow, 2015). Hal tersebut juga diungkapkan oleh salah satu partisipan yang mengatakan bahwa lidah buaya berfungsi untuk mendinginkan luka bakar.

Luka bakar dapat menyebabkan timbulnya infeksi. Untuk mengantisipasi adanya infeksi pada luka bakar dapat dengan menutup luka menggunakan kain bersih dan tidak berbulu atau bisa juga dengan menggunakan plastik (Moffat, 2005). Pada penelitian ini terdapat partsisipan yang memberikan antibiotik dan menutup dengan perban untuk mengurangi terpaparnya dari infeksi.

Pada kehidupan sehari-sehari masih ditemukan masyarakat yang memberikan pertolongan pertama pada luka bakar dengan menggunakan bahan rumah tangga dan kosmetik. Hal tersebut juga ditemukan pada penelitian ini bahwa terdapat partisipan yang memberikan minyak goreng, odol dan konsmetik sebagai pemberian pertolongan pertama pada luka bakar. Selain itu, hal-hal yang perlu diperhatikan dalam memberikan pertolongan pertama yaitu tidak menyentuh luka bakar atau memecahkan bagian yang melepuh dan tidak mengoleskan cairan, lemak dan pasta pada area luka (Moffat, 2005). Menurut penelitian yang dilakukan Hamdiya et al (2015) mengatakan bahwa pemberian krim, salep, lotion atau mentega/minyak goreng yang dioleskan pada luka bakar ringan dapat memicu adanya infeksi. Selain itu, pemberian pertolongan pertama dengan non-konvensional atau obat tradisional yang tidak tepat dapat menunda dari proses penyembuhan (Hamdiya et al, 2015).

Obat tradisional yang dipercaya masyarakat dapat menyembuhkan luka bakar salah satunya yaitu pemberian lidah buaya. Pada penelitian ini terdapat partisipan yang memberikan lidah buaya sebagai pemberian pertolongan pertama. Ibu menganggap bahwa lidah buaya memiliki efek mendinginkan terhadap luka karena terbakar. Lidah buaya merupakan tanaman yang mengandung imunomudolator, antikanker, protektif gastro, antijamur dan antiinfalamasi (Nazir, et al, 2018). Lidah buaya ini memiliki manfaat terhadap masalah kulit seperti luka, cedera, dan penyakit infeksi (Akaberi, Sobhani, Javadi, Sahebkar, dan Ahmad, 2016). Namun terdapat dampak lain dari penggunaan lidah buaya pada luka, hal tersebut diungkapkan oleh penelitian Nazir et al (2018) yang mengatakan bahwa penggunaan lidah buaya pada luka bakar terbuka atau dalam dapat menimbulkan reaksi alergi seperti kulit ruam, tetapi penggunaan pada permukaan kulit aman digunakan jika tidak terdapat cedera.

Penyebab luka bakar pada anak-anak biasanya disebabkan oleh uap panas, tersiram air panas/minuman panas, kecelakaan ketika bermain dan adanya kontak dengan api (Gill P, 2017). Tingkat keparahan dari luka bakar tergantung pada luas permukaan tubuh, kedalaman, warna, komplikasi, dan penyebab dari luka (Panacea, 2013). Sejauh mana kerusakan jaringan tubuh dapat dijadikan indikator keadaan luka seseorang. Keadaan luka dikasifikasikan menjadi 3 derajat yaitu luka 
bakar derajat I, derajat II, dan derajat III (Hamdiya A, et al, 2015). Pada penelitian ini ditemukan 2 partisipan yang memiliki luka bakar derajat II dan 5 partisipan lainnya pada derajat 1 . Tingkat dari keparahan luka bakar ini dapat mempengaruhi pemberian pertolongan pertama yang diberikan (Panacea, 2013).

Luka bakar pada anak-anak biasanya akan menimbulkan nyeri dan kaget, sehingga biasanya anak-anak akan meresposnya dengan menangis. Menurut Holmstrom, Junehag, Lundberg, dan Haggstrom (2019) menangis merupakan salah satu respon dari nyeri pada anak yang sering disebabkan oleh beberapa bentuk trauma seperti kecelakaan atau luka bakar. Adanya nyeri yang disebabkan dari luka bakar menyebabkan perlunya tindakan pengurangan nyeri yang dilakukan oleh ibu. Berdasarkan hasil wawancara ditemukan bahwa untuk mengurangi nyeri anak diberikan distraksi seperti diberi jajan, jalan-jalan dan digendong. Kejadian cedera yang dialami anak-anak yang disertai respon seperti menangis dapat menyebabkan ibu menjadi panik, khawatir dan bingung. Ketika ibu mengalami panik, khawatir dan kaget hal tersebut akan mempengeruhi pada pemberian pertolongan pertama. Hal tersebut di nyatakan pada penelitian Wei, Chen, $\mathrm{Li}, \mathrm{Ma}$, Peng, dan Huang (2013) yang mengatakan bahwa ketika anak mereka mengalami cedera yang tidak disengaja maka orang tua akan panik dan mengirim anaknya ke rumah sakit tanpa memberikan pertolongan pertama terlebih dahulu.

Tingkat keparahan dari cedera luka bakar memiliki efek pada psikososial postburn (Bakker, Maertens, Son, Loey, dan Nee Van, 2013). Luka bakar juga selain memiliki dampak pada fisik anak, dapat berdampak pada psikologis anak juga seperti adanya trauma, post traumatic disorder (PTSD), phobia dan cemas (Lubis, Hasanah, dan Dewi 2015). Selain anak yang mengalami trauma, ditemukan adanya tingkat stress pascatrauma, gejala depresi, dan perasaan bersalah pada orang tua setelah anaknya terkena luka bakar (Bakker et al, 2013). Pernyataan tersebut sesuai pada penelitian mengenai konsekuensi psikologi luka bakar pediatrik dari perspektif anak dan keluarga yang menyatakan bahwa adanya hubungan antara reaksi stress trauma orang tua dengan reaksi trauma jangka pendek pada anak (Bakker et al, 2013).

Pemberian pertolongan pertama dipengaruhi dari adanya persepsi orang tua mengenai luka bakar pada anak-anak. Persepsi merupakan suatu pandangan seseorang mengenai pengalaman tentang objek atau peristiwa bagaimana cara melihat, mengartikan dan menilai sesuatu yang diperoleh berdasarkan informasi dan penafsiran pesan (Rahardian, 2015). Hal tersebut dinyatakan pada penelitian tahun 2019 mengenai perubahan persepsi orang tua setelah terjadi resiko cedera yang mengatakan bahwa adanya persepsi resiko cedera berkaitan dengan perilaku pencegahan orang tua terhadap resiko cedera (Ishikawa, Masse, dan Brussoni, 2019).

Faktor lain yang mempengaruhi pertolongan pertama pada luka bakar menurut pada penelitian Hamdiya et al (2015) mengatakan bahwa sebagian besar orang tidak sadar dan kurang memiliki pengetahuan mengenai pemberian pertolongan pertama pada korban luka bakar, selain itu faktor dari keyakinan dan budaya seseorang juga mempengaruhi dari pemberian pertolongan pertama pada luka bakar.

\section{SIMPULAN}

Berdasarkan hasil penelitian yang dilakukan di kota Semarang dengan jumlah partisipan sebanyak 7 orang mengenai gambaran pengalaman ibu melakukan pertolongan pertama luka bakar pada anak umur 1-4 tahun di kota Semarang dapat disimbulkan bahwa pertolongan pertama yang diberikan ibu ketika anak terkena luka bakar seperti memberikan air, lidah buaya, 
pasta gigi, minyak goreng, dan tender care/orifflame. Keadaan luka bakar yang dialami yaitu mulai dari luka bakar ringan hingga luka bakar sedang. Ditandai dengan kulit berwarna merah, kulit tidak mengelupas tapi ada juga kulit yang mengkerut serta luka terdapat pada area kaki dan tangan dengan luas $<15 \%$, sedangkan yang memiliki luka bakar sedang ditandai dengan warna kulit merah, kulit mengelupas dan berair yang terjadi pada area dada, perut dan pundak dengna luas $>15 \%$. Respon anak saat terkena luka bakar yaitu menangis dan mengatakan perasaannya serta diatasi untuk menguranginya dengan memberikan jajan, diajak jalan-jalan, dan digendong. Sedangkan reaksi pada ibu saat anaknya terkena luka yaitu panik, khawatir, kaget, bingung, dan kasihan. Dampak psikologi dari adanya luka bakar menyebabkan trauma pada ibu dan anak, namun ada juga yang tidak mengalami trauma. Persepsi ibu mengenai luka bakar dinyatakan bahwa berbahaya dan tidak berbahaya. Upaya yang dilakukan oleh ibu untuk mengurangi kejadian tidak terulang lagi yaitu dengan meningkatkan kewaspadaan dan tidak menggunakan barang penyebab dari luka bakar. Saran bagi ibu atau orang tua agar senantiasa memeriksakan anaknya ketikda mengalami luka bakar ke pelayanan kesehatan terdekat dan adanya pendokumentasian oleh pelayanan kesehatan karena masih banyak kejadian luka bakar yang belum terdokumentasikan. Selain itu, penelitian ini juga dapat dijadikan sebagai gambaran bagi pelayanan kesehatan dalam memberikan intervensi berupada edukasi kepada masyarakat mengenai pertolongan pertama pada luka bakar.

\section{UCAPAN TERIMAKASIH}

Penulis ingin mengucapkan terima kasih kepada semua informan dalam penelitian ini.

\section{REFERENSI}

Akaberi, M., Sobhani, Z., Javadi, B., Sahebkar, A., Ahmad, S. (2016). Therapeutic effects of Aloe spp in traditional and modern medicine: A review. Biomed Pharmacother.84:759-72.

Bakker, A., Maertens, KJP., Son, MJM Van., Loey, NEE Van. (2013). Psychological consequences of pediatric burns from a child and family perspective: A review of the empirical literature. Clin Psychol Rev.33(3):361-71.

Barik, AL., Rohmah, N., Hamid M. (2015). Hubungan Sikap Ibu dengan Antisipasi Cedera pada Anak Usia Pre School di Desa Karanganyar Ambulu. J Kesehat. 1(1):1-8.

Gill P. (2017). Early management of paediatric burn injuries. Paediatr Child Health.;27(9):406-14.

Hamdiya, A., Pius, A., Ken, A., Ekow, HP. (2015). The trend of acute burns pre-hospital management. J Acute Dis.4(3):210-3.

Holmstrom, MR., Junehag, L., Lundberg, S., Ek, B., Haggstrom M. (2019). Nurses' experiences of prehospital care encounters with children in pain. Jurnal International Emergency Nurse. 43(1):23-8.

Ishikawa, T., Masse, LC., Brussoni, M. (2019). Changes in parents' perceived injury risk after a medically-attended injury to their child. Prev Med Reports.13(1):146-52.

Kattan, AE., AlShomer, F., Alhujayri, AK., Addar, A., Aljerian A. (2016). Current Knowledge of Burn Injury First Aid Practices and Applied Traditional Remedies: a Nationwide Survey. Burn Trauma. 4(1):37.

Kusbiantoro D. (2014). Praktik Pencegahan Cedera pada Anak Usia Toddler Ditinjau dari Pengetahuan dan SIkap Orang Tua Tentang Bahaya Cedera Di Desa Kembangbahu Keceamtan Kembangbahu Kabupaten Lamongan. Surya. 02(18):32-40.

Kuschithawati, S., Magetsari R, Ng N. (2007). Faktor Risiko Terjadinya Cedera pada Anak Usia Sekolah Dasar. Ber Kedokt Masy.23(3):131-41.

Lam, NN., Li, F., Tuan CA, Huong, HTX. (2017). To Evaluate First Aid Knowledge On Burns Management Amongst High Risk Groups. Burn Open.1(1):29-32.

Lubis, P., Hasanah, O., Dewi, AP. (2015). Gambaran 
Tingkat Risiko Cedera pada Anak Usia Sekolah. JOM. 2(2):1335-44.

Mignon, S. (2008). Burns and children. World Rep Child Inj Prev.(121):79-98.

Moffat, SC. (2005). Pertolongan pertama untuk anak. Jakarta: Gramedia Pustaka Utama.

Muyassaroh, S. (2015). Hubungan Self Efficacy dengan Tingkat Pengetahuan Ibu dalam Penanganan Pertama Luka Bakar pada Anak Usia Pra-sekolah di Desa Jombor Bendosari Sukoharjo. Keperawatan STIKes Kusuma Husada Surakarta.83:1-8.

Nazir, A., Kashif, M., Khan, I., Zia, R., Murid, M., Abrar, M., et al. (2018). The therapeutic properties and applications of Aloe vera : A review. J Herb Med.12(1):1-10.

Panacea TBM. Basic life support. Jakarta: EGC; 2013.

Rahardian. (2015). Hubungan Antara Persepsi Diri Terhadap Pengambilan Keputusan Dalam Menentukan Tujuan Studi. Jurnal Psikol. 2017;1(1):1-10.

Santoso, B., Sulistiowati, E., Sekartuti., Lamid A. (2013). Riset Kesehatan Dasar Provinsi Jawa Tengah. Jakarta: Lembaga Penerbitan Badan Litbangkes.

Sari, SM. (2015). Pengalaman Prehospital Keluarga dalam Penanganan Luka Bakar di RSUD Sukoharjo. Nurs Sci. 45:1-13.

Wei, Y., Chen, L., Li, T., Ma, W., Peng, N., Huang, L. (2013). Self-efficacy of first aid for home accidents among parents with 0 - to 4 -year-old children at a metropolitan community health center in Taiwan. Accid Anal Prev. 52:182-7. 